\title{
Ribozyme Pharmacokinetic Screening For Predicting Pharmacodynamic Dosing Regimens
}

\author{
Tom J. Parry ${ }^{1}$, Karyn S. Bouhana ${ }^{2}$, Karin S. Blanchard ${ }^{2}$, \\ Pamela A. Pavco', and Jennifer A. Sandberg ${ }^{2 *}$ \\ ${ }^{1}$ Human Genome Sciences, Inc., 9410 Key West Ave., \\ Rockville, MD 20850, USA \\ ${ }^{2}$ Ribozyme Pharmaceuticals, Inc., 2950 Wilderness Place, \\ Boulder, CO 80301, USA
}

\begin{abstract}
A significant amount of research has been devoted to the chemical stabilization of synthetic ribozymes, in part, so that applications to systemic disease can be explored. A nuclease-stabilized synthetic hammerhead ribozyme, ANGIOZYME ${ }^{\mathrm{TM}}$, has been developed which targets the mRNA encoding a vascular endothelial growth factor receptor, Flt-1. Because the stimulation of this receptor may contribute to tumor neovascularization and subsequent tumor growth and metastasis, we have explored the systemic use of ANGIOZYME $^{\mathrm{TM}}$ to down regulate this receptor in a syngeneic model of metastatic cancer. We describe here the application of pharmacokinetic analysis to the selection of a dosing regimen for pharmacodynamic screening in this murine cancer model. These studies demonstrate that the appropriate application of pharmacokinetic analysis is necessary for the optimization of systemic pharmacodynamic studies using synthetic ribozymes.
\end{abstract}

\section{Introduction}

The discovery of cis-cleaving RNA by Cech et al. (1) and Guerrier-Takada et al. (2) in the early 1980's and the subsequent research leading to trans-cleavage (3) made possible the development of ribozymes as a new class of therapeutics. Synthetic ribozymes comprised of all ribonucleotides are susceptible to endo- and exonuclease breakdown (4). Ribozymes containing only unmodified ribonucleotides would therefore be viable as therapeutics only when expressed by a vector system (e.g. a gene therapy approach). To overcome the stability limitations imposed by all-ribonucleotide ribozymes, much effort has been devoted to the chemical stabilization of synthetic ribozymes while maintaining their ability to cleave substrate mRNA (4).

The recent advances in ribozyme endonuclease stabilization have enabled synthetic ribozymes to be considered as potential therapeutic agents. Although several studies have examined the pharmacokinetics of stabilized oligonucleotides in several species, little is known about the pharmacokinetic profile of synthetic ribozymes in animal systems. In general, stabilized oligonucleotides are rapidly distributed following intravenous administration $\left(\mathrm{t}_{1 / 2} \alpha\right.$ on the order of minutes) with a species and dose- dependent elimination profile exemplified by half-lives of elimination from minutes/hours (5-11) to days (12-14). The major routes of elimination for these oligonucleotides are the kidney and the liver (12). The only published work regarding ribozyme pharmacokinetics is that of Desjardins and co-workers describing the distribution of a ribozyme targeting rat $\mathrm{P} 4503 \mathrm{~A} 2 \mathrm{mRNA}(15)$. In that study, the 2'-Oallyl-modified 38-mer ribozyme modified with a 5'fluorescein group was quickly distributed ( $\left.\mathrm{t}_{1 / 2} \alpha 12 \mathrm{~min}\right)$ and eliminated with a half-life of $6.5 \mathrm{~h}$.

There have been only four studies published to date that have addressed locally administered synthetic ribozyme pharmacodynamics in animals. A 2'-O-allyl modified ribozyme targeting amelogenin mRNA inhibited normal enamel formation after submandibular injection in neonatal mice (16). When injected intraarticularly in the knee, a stabilized ribozyme targeting stromelysin message reduced IL-1-stimulated stromelysin mRNA in rabbit synovium (17). An anti-protein kinase $\mathrm{C} \alpha$ mRNA targeting ribozyme, comprised totally of 2'-amino-modified ribonucleotide analogs, reduced subcutaneously implanted glioma tumor growth in rats (18). Finally, an in vitro transcribed ribozyme targeting TNF- $\alpha$ mRNA complexed with cationic lipids injected within the peritoneum decreased lipopolysaccharide-induced TNF- $\alpha$ expression in peritoneal cells obtained by lavage (19). Although this ribozyme was not chemically modified, use of a cationic lipid formulation likely enhanced the circulation time compared with unformulated ribozyme. Unfortunately, no studies have yet been published which explore the treatment of disseminated disease with systemically delivered synthetic ribozymes.

Our laboratory has investigated the antitumor and antimetastatic applications of chemically modified synthetic ribozymes that possess antiangiogenic activity. The process of angiogenesis is critical to the growth of solid tumors and metastasis (20). Vascular endothelial growth factor (VEGF) is a selective and potent activator of angiogenesis (21) and is present in numerous human tumor types (22). Two major VEGF receptor subtypes exist in man (KDR and Flt-1) and, although both receptors appear to be involved with angiogenesis, their precise roles in this process are poorly understood. Because of the potential role of the Flt-1 receptor in regulating vascular assembly and its possible involvement in tumor angiogenesis (23, 24), we have developed a modified hammerhead ribozyme (ANGIOZYME ${ }^{\mathrm{TM}}$ ) which targets Flt-1 mRNA for anticancer applications.

With the relative paucity of pharmacokinetic and pharmacodynamic data for chemically modified ribozymes, it is necessary to consider the use of pharmacokinetic studies to predict appropriate dosing routes and regimens for pharmacodynamic experimentation. This is especially important since differences typically exist between ribozyme chemistry, experimental species, disease model, 


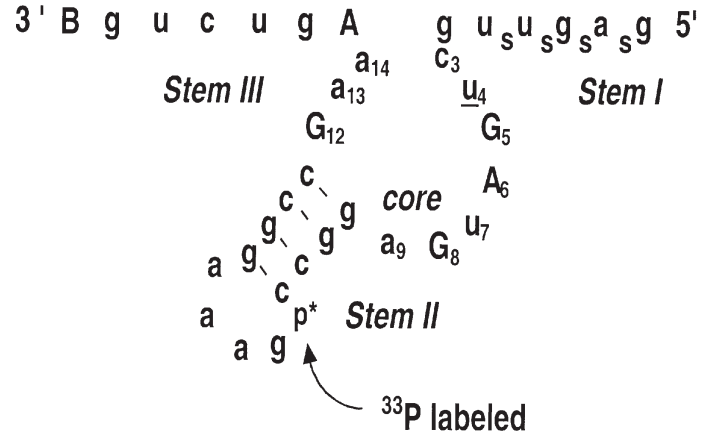

Lowercase: 2'-0-Me nucleotide Uppercase: ribonucleotide B: inverted 2' deoxy abasic s: phosphorothioate $\underline{\mathrm{u}}_{4}:$ 2' $^{\prime}$-C-allyl-uridine nucleotide

Figure 1. Structure of ANGIOZYMETM (RPI.4610). Nucleotide and backbone chemical modifications are listed. ANGIOZYME ${ }^{\text {TM }}$ was internally labeled with $\left[{ }^{33} \mathrm{P}\right]$ for quantitation of pharmacokinetic samples.

target tissue, etc. We have employed the use of pharmacokinetic analysis to optimize dosing regimens for ANGIOZYME $^{\mathrm{TM}}$ in anticancer studies and report here an application of this strategy in a murine model of metastatic lung carcinoma.

\section{Pharmacokinetic Analysis}

A pharmacokinetic study was designed to examine which mode of systemic administration would provide the greatest ribozyme exposure in pharmacodynamic studies. A variety of routes of administration could have been used for systemic dosing of this ribozyme, but intravenous administration was selected because absorption is generally considered to be instantaneous and complete.

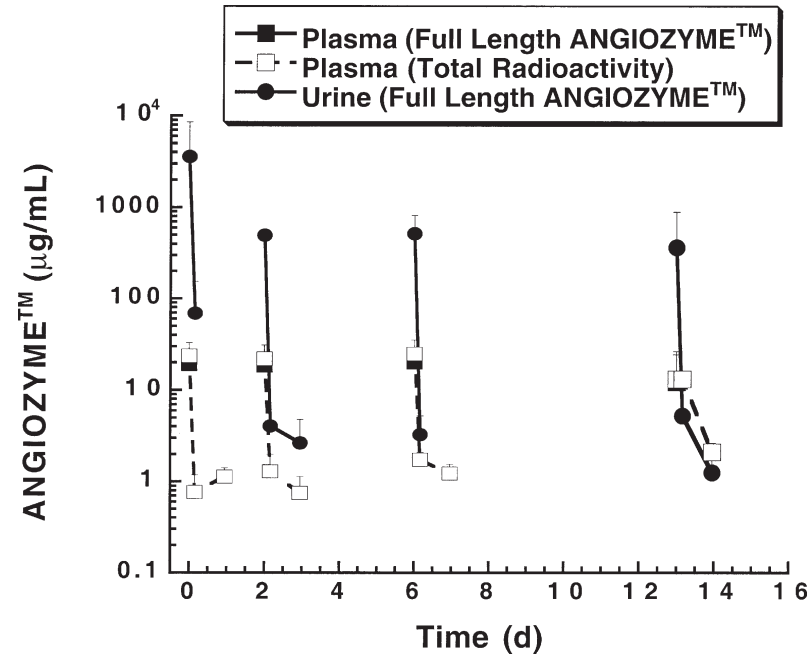

Figure 2. Ribozyme concentrations in plasma and urine after daily intravenous bolus administration of ANGIOZYME ${ }^{\text {TM }}$ for 14 days. Animals were instrumented with indwelling jugular vein catheters for daily bolus administration of $30 \mathrm{mg} / \mathrm{kg}$ ANGIOZYMETM supplemented with $5 \times 10^{6} \mathrm{cpm} /$ $\mathrm{d}$ of labeled $\left[{ }^{33} \mathrm{P}\right]$ ANGIOZYME ${ }^{\mathrm{TM}}$. Concentration data are shown as mean and standard deviation.
However, since the pattern of exposure could be quite different depending on the length of the intravenous infusion, this study compared ANGIOZYMETM distribution in plasma and tissue after bolus or continuous intravenous administration. Since inhibiting murine tumor growth is likely to require prolonged exposure to an antiangiogenic ribozyme, the distribution of ANGIOZYMETM was examined during a two-week treatment period. This study was conducted in the same animal model that was used for examining the antitumor and antimetastatic properties of ANGIOZYME ${ }^{\text {TM }}$ (see Pharmacodynamic Screening section below).

\section{Pharmacokinetic Study Methods}

ANGIOZYME ${ }^{T M}$ was synthesized according to the method of Wincott et al. (25). As shown in Figure 1, ANGIOZYMETM is a 35-mer containing several nucleotide modifications previously shown to enhance ribozyme stability (4). For internal labeling with $\left[{ }^{33} \mathrm{P}\right]$, ANGIOZYME ${ }^{\mathrm{TM}}$ was synthesized in two halves. The 3 ' half-ribozyme was 5 ' endlabeled using T4 polynucleotide kinase and [ $\left.\gamma^{33} \mathrm{P}\right]$ ATP. The two half-ribozymes were then ligated together using T4 RNA ligase. Full length internally labeled ANGIOZYMETM was purified from ribozyme halves and unincorporated $\left[\gamma^{33} \mathrm{P}\right]$ ATP by polyacrylamide gel electrophoresis (PAGE).

All studies involving animals were performed in accordance with the National Research Council's Guide for the Care and Use of Laboratory Animals (26), USDA regulations, and the policies and procedures of the RPI Institutional Animal Care and Use Committee. Since the pharmacokinetics of ANGIOZYME ${ }^{\mathrm{TM}}$ could be altered by complications of metastatic disease, Lewis lung carcinoma (LLC-HM) tumor-bearing animals were used for this study (see Pharmacodynamic Study Methods). Three days prior to the initiation of dosing, C57BL/6 mice were inoculated subcutaneously with $5 \times 10^{5}$ LLC-HM tumor cells (kindly provided by Dr. Michael O’Reilly, Harvard University) obtained from tumor brei preparations. On post-inoculation day 3 , jugular catheters were implanted in all animals. Catheters were attached to subcutaneously implanted Alzet osmotic minipumps for continuous infusion or were exteriorized for daily bolus ANGIOZYME ${ }^{\mathrm{TM}}$ administration. ANGIOZYME ${ }^{T M}$ was administered at a dose of $30 \mathrm{mg} / \mathrm{kg} /$ d supplemented with $5 \times 10^{6} \mathrm{cpm} / \mathrm{d}\left[{ }^{33} \mathrm{P}\right]$ ANGIOZYMETM by bolus or continuous infusion. Animals were euthanized by $\mathrm{CO}_{2}$ inhalation $15 \mathrm{~min}, 4 \mathrm{~h}$ and $23 \mathrm{~h}$ on days $1,3,7$ and 14 after bolus administration or days 1, 3, 7 and 14 after continuous infusion. Blood was sampled via cardiac puncture and added to heparinized tubes. When possible, urine was collected from a glass dish placed beneath the animals during $\mathrm{CO}_{2}$ inhalation. Tissue including femur, liver, lung and tumor was collected and immediately frozen on dry ice. Plasma, urine and tissue were stored at $-70^{\circ} \mathrm{C}$ until analyzed for ANGIOZYMETM concentrations.

Total radioactivity in plasma and urine was quantified by liquid scintillation. Frozen tissue was pulverized and digested in proteinase $\mathrm{K}$ containing buffer prior to liquid scintillation. The percent of total radioactivity associated with full-length ANGIOZYME ${ }^{\mathrm{TM}}$ was determined by phosphorimage analysis of samples separated by PAGE. 


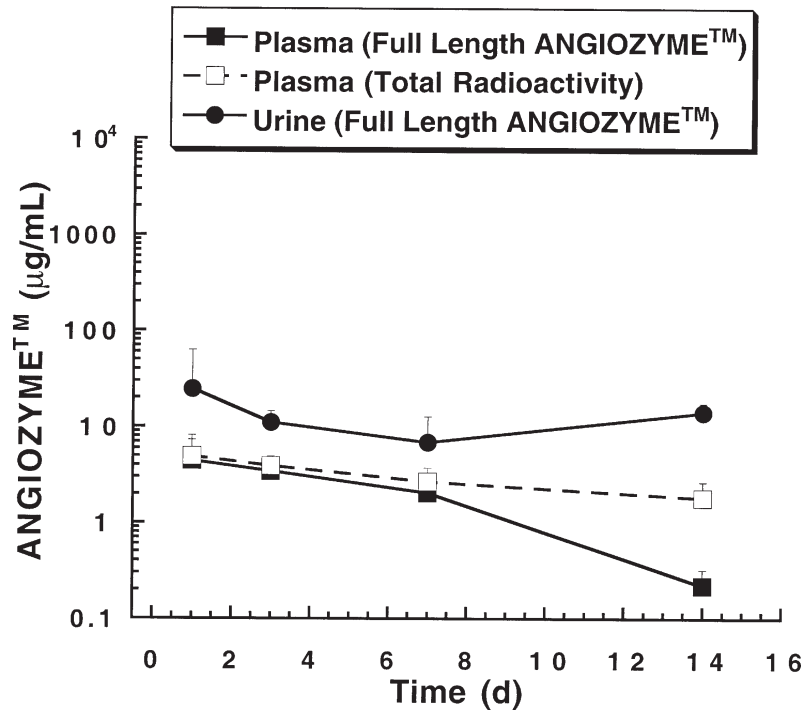

Figure 3. Ribozyme concentrations in plasma and urine after continuous administration of ANGIOZYME ${ }^{\mathrm{TM}}$ for 14 days. Animals were instrumented with indwelling jugular vein catheters attached to Alzet osmotic minipumps. ANGIOZYME ${ }^{\top M}$ was administered as a continuous infusion of $30 \mathrm{mg} / \mathrm{kg} / \mathrm{d}$ ANGIOZYME
supplemented with $5 \times 10^{6} \mathrm{cpm} / \mathrm{d}$ of labeled $\left[{ }^{33} \mathrm{P}\right]$ ANGIOZYME ANM $^{\mathrm{TM}}$. supplemented with $5 \times 10^{6} \mathrm{cpm} / \mathrm{d}$ of labeled $\left[{ }^{33} \mathrm{P}\right]$ ANGIOZYN
Concentration data are shown as mean and standard deviation.

\section{Pharmacokinetic Study Results and Discussion} Systemic administration of ANGIOZYME ${ }^{\mathrm{TM}}$ by bolus or continuous infusion resulted in very different patterns of plasma exposure. As would be expected, higher plasma concentrations of ANGIOZYME ${ }^{\text {TM }}$ were achieved after bolus administration $(18.7 \pm 7.1 \mu \mathrm{g} / \mathrm{ml})$ compared with continuous infusion $(4.4 \pm 2.9 \mu \mathrm{g} / \mathrm{ml})$. Although radioactivity was detected at the three time points examined each day after bolus administration, full length ANGIOZYME ${ }^{\mathrm{TM}}$ was detected in plasma only at the 15 min time point (Figure 2). In contrast, full length ANGIOZYME ${ }^{\mathrm{TM}}$ was observed at every time point examined after continuous infusion (Figure 3). ANGIOZYME ${ }^{\mathrm{TM}}$ concentrations in plasma were at steady state for the first 7 days after continuous infusion but declined significantly by day 14 (Figure 3 ). Since total radioactivity remained at steady-state over this same time period, the reduction of full length ANGIOZYME ${ }^{\mathrm{TM}}$ plasma concentrations on day 14 is likely due to an increase in ribozyme catabolism. Changes in other elimination processes (i.e. increased urinary elimination or tissue sequestration) should have resulted in a reduction in total plasma radioactivity.

As demonstrated in Figure 2, ANGIOZYME ${ }^{T M}$ was rapidly eliminated after a bolus intravenous injection. Since ANGIOZYME ${ }^{\text {TM }}$ could not be detected $4 \mathrm{~h}$ after bolus administration, the elimination half-life of ANGIOZYME ${ }^{T M}$ was predicted to be less than an hour in the mouse. This is much shorter than the half-life of approximately $6 \mathrm{~h}$ reported for the chemically modified ribozyme targeting P450 3A2 mRNA (15). Although the half-life of a ribozyme with the same chemical modifications as ANGIOZYME ${ }^{\mathrm{TM}}$ is extremely long in vitro, 11 days in human serum (4), renal elimination and tissue distribution added to the process of catabolism resulting in enhanced clearance of

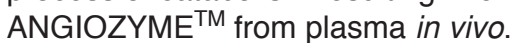

Plasma clearance of ANGIOZYME ${ }^{T M}$ by renal elimination and tissue distribution was observed in this study. Regardless of the mode of administration, concentrations of ANGIOZYMETM in urine were always higher than plasma concentrations (Figures 2 and 3 ). This suggests that renal elimination plays a significant role in the overall in vivo clearance of ANGIOZYME ${ }^{\mathrm{TM}}$. While renal elimination of another chemically modified synthetic ribozyme targeting rat cytochrome P-450 mRNA has been observed, only $2.4 \%$ of the total dose was eliminated in the urine $48 \mathrm{~h}$ after administration (15). Full length ANGIOZYME ${ }^{\mathrm{TM}}$ was observed not only in urine but also in several tissues including femur, kidney and lung after either mode of administration (data not shown). Due to small tumor volumes on post-inoculation day 14, tumor concentrations of ANGIOZYME ${ }^{\mathrm{TM}}$ could not be consistently quantified.

The mode of administration for pharmacodynamic studies was selected based on plasma concentration data since it could not be determined whether bolus or continuous intravenous administration resulted in higher tumor concentrations. This pharmacokinetic study indicated that continuous intravenous administration of ANGIOZYME ${ }^{\mathrm{TM}}$ resulted in sustained plasma concentrations of full-length ribozyme for the two week administration period. In contrast, plasma concentrations of ANGIOZYME ${ }^{\mathrm{TM}}$ were not sustained nor could be measured consistently even $4 \mathrm{~h}$ post-infusion using a bolus administration regimen. Based on these pharmacokinetic results, a continuous intravenous dosing regimen was selected for follow-on pharmacodynamic modeling in the Lewis lung carcinoma model in mice.

\section{Pharmacodynamic Analysis}

The selection of an appropriate model is critical to pharmacodynamic screening. Since our interest focused on anticancer applications of systemically administered ANGIOZYME $^{\mathrm{TM}}$, we chose to use a Lewis lung carcinoma tumor that expresses Flt-1 mRNA (data not shown) and whose angiogenesis is VEGF-dependent (27). This highly metastatic form of Lewis lung carcinoma spontaneously generates large numbers of lung macrometastases without resection of the primary tumor in immunocompetent mice (28). The use of animals with intact immune systems allowed for the surgical manipulation required for the introduction of indwelling jugular catheters without a high degree of morbidity/mortality secondary to infection.

\section{Pharmacodynamic Study Methods}

Female C57BL/6 mice were inoculated with LLC-HM cells and three days later equipped with indwelling jugular catheters as described in the Pharmacokinetic Study Methods section. On the same day, Alzet osmotic minipumps (12 $\mu \mathrm{l} /$ day flow rate) filled with ANGIOZYME ${ }^{\mathrm{TM}}$, an attenuated control ribozyme (RPI.4611) or saline solutions were implanted subcutaneously and attached to the indwelling jugular catheter. RPI.4611 has the same binding arms as ANGIOZYME ${ }^{\mathrm{TM}}$, but also has two nucleotide changes in the core which greatly diminishes its catalytic activity (data not shown). ANGIOZYME ${ }^{\mathrm{TM}}$ and the attenuated control RPI.4611 were dissolved in saline 
at a concentration of $51 \mathrm{mg} / \mathrm{ml}$. Animals received a cumulative daily dose of $30 \mathrm{mg} / \mathrm{kg}$ of ANGIOZYME ${ }^{\mathrm{TM}}$ or RPI.4611 for 14 days. Saline control animals received 12 $\mu \mathrm{l}$ normal saline per day for the same time period.

The long and short axes (length and width, respectively) of tumors were measured with microcalipers every other day from post-inoculation days 4 to 24 . Tumor volume was calculated by the formula: 0.5 (Length*Width ${ }^{2}$ ). Twenty-five days following inoculation, animals were euthanized, tumors and lungs removed and the number of macrometastases were counted under a dissecting microscope at a magnification of $25 X$.

Group tumor volume means obtained every other day from 14 through 24 days post-inoculation for each treatment were subjected separately to normality testing and oneway analysis of variance. Group mean comparisons versus saline were made using Dunnett's post-hoc test for significance (alpha $=0.05$ ). Group means for ANGIOZYMETM and RPI.4611 were compared using a Tukey-Kramer post-hoc test for significance (alpha $=0.05$ ). The mean number of pulmonary metastases from each treatment group was subjected to normality testing and one-way analysis of variance followed by a Dunnett's test for significance (alpha $=0.05$ ) using the saline group as the control.

\section{Pharmacodynamic Study Results and Discussion}

The effects of continuous treatment with $30 \mathrm{mg} / \mathrm{kg} / \mathrm{d}$ ANGIOZYME ${ }^{\mathrm{TM}}$ over $14 \mathrm{~d}$ on Lewis lung carcinoma primary tumor growth are shown in Figure 4. At the completion of the continuous intravenous administration period (day 18), ANGIOZYME ${ }^{\mathrm{TM}}$ dramatically reduced primary tumor volume compared to saline and attenuated controls $(p<0.05)$. The effect of the $14 \mathrm{~d}$ treatment was followed out to day 24. Even though treatment ended 7 days prior to the final tumor volume measurement, a significant antitumor effect was still observed between ANGIOZYME ${ }^{\mathrm{TM}}$ and the saline and the attenuated ribozyme controls $(p<0.05)$.

The impact of continuous 14 day treatment with 30 $\mathrm{mg} / \mathrm{kg} / \mathrm{d}$ ANGIOZYME ${ }^{\mathrm{TM}}$ on lung macrometastases was also assessed in the same animals (Figure 5). ANGIOZYME $^{\mathrm{TM}}$ significantly reduced the number of pulmonary macrometastases in Lewis lung tumor bearing mice compared with saline treated animals. The dosematched attenuated control had no effect on the number of pulmonary metastases in this model. In a separate study, reductions in neither lung macrometastases nor on primary tumors were observed following daily bolus intravenous administration of $30 \mathrm{mg} / \mathrm{kg}$ ANGIOZYME ${ }^{\mathrm{TM}}$ (data not shown).

\section{Conclusions}

The above studies demonstrate how pharmacokinetic evaluation can be used to help optimize the selection of efficacious dosing regimens. In fact, the integration of pharmacokinetic and pharmacodynamic information is particularly important when evaluating novel compounds such as ribozymes. The rapid in vivo elimination of ANGIOZYME ${ }^{\text {TM }}$ could not have been predicted based on its substantial in vitro stability in human serum (4). Although structural modifications have imparted relatively high nuclease resistance to ribozymes, the integrated processes of elimination in vivo substantially reduce ribozyme halflives compared with in vitro half-lives. Continuous infusion of ANGIOZYME ${ }^{\text {TM }}$ via osmotic minipump provided the necessary plasma and tissue exposure needed to observe the antitumor and antimetastatic properties of this ribozyme in a murine model of cancer. As ribozyme therapies are applied to larger preclinical animal models and ultimately humans, pharmacokinetic evaluation will play an important and necessary role in the development of safe and effective dosing regimens. In addition, pharmacokinetic analysis will provide for direct correlation between exposure and efficacy as well as toxicity. The application of a systemically delivered ribozyme for the treatment of disseminated disease such as metastatic cancer represents an important milestone in the development of ribozymes as human therapeutics.

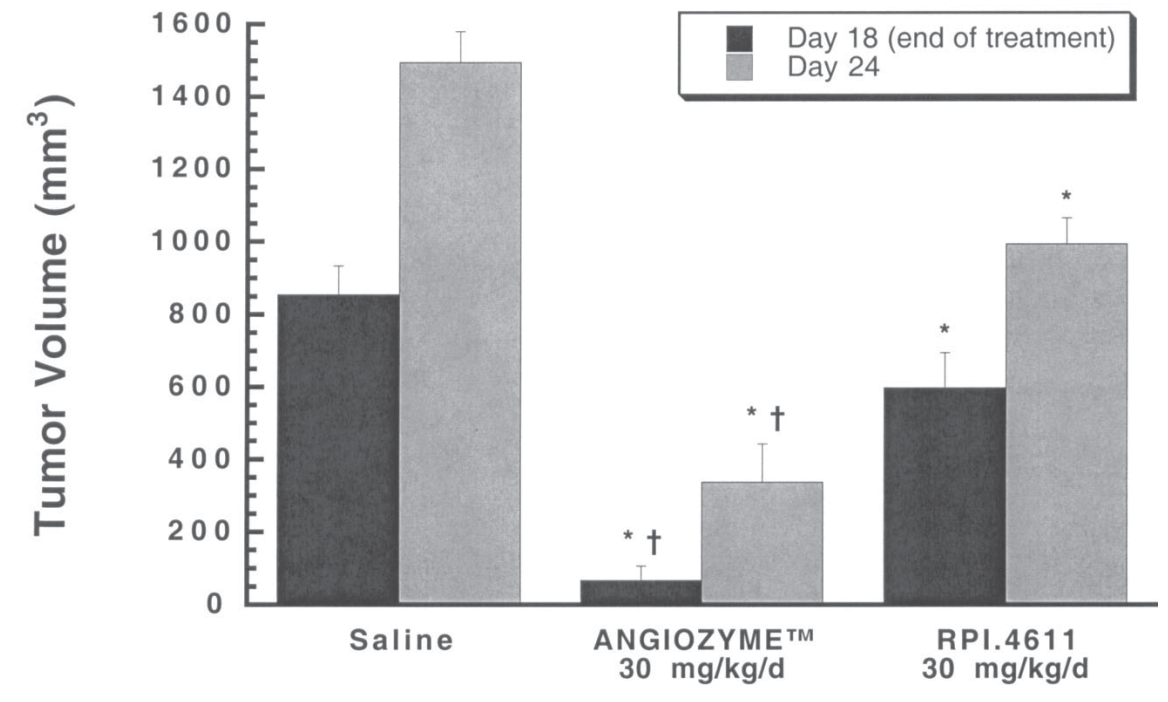

Figure 4. Effects of ANGIOZYME ${ }^{\mathrm{TM}}$ on Lewis lung primary tumor growth in mice. Shown are tumor volumes on day 18 (immediately after the completion of the continuous dosing period) and day 24 post-inoculation ( 7 days after the completion of dosing) for saline. ANGIOZYME $^{\mathrm{TM}}$ and the attenuated control, RPI.4611. Data reported as mean tumor volume \pm SEM, $n=7-10$ per group ${ }^{*} p<0.05$ vs. saline by Dunnett's, $t p<0.05$ vs. attenuated control by Tukey-Kramer. 


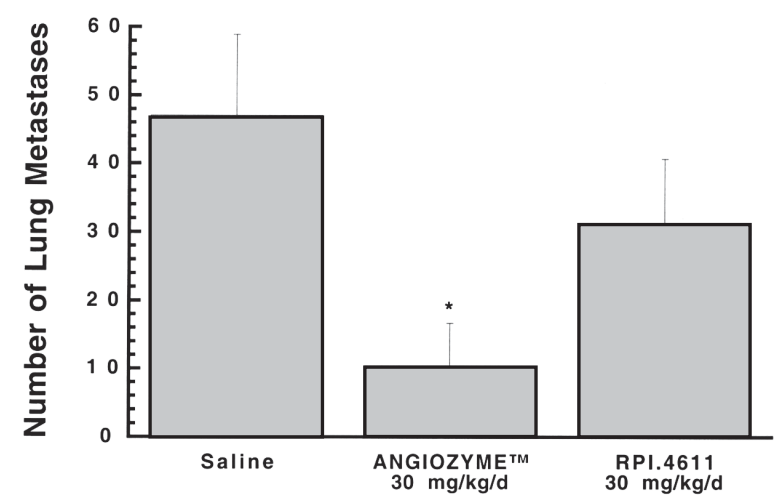

Figure 5. Effects of ANGIOZYME ${ }^{\mathrm{TM}}$ on the number of Lewis lung carcinoma pulmonary macrometastases in mice. Shown are the mean numbers of lung macrometastases eight days after the completion of a 14 day dosing regimen with saline, ANGIOZYME ${ }^{\mathrm{TM}}$ or the attenuated control, RPI.4611. Data are reported as mean number of lung metastases \pm SEM, $n=7-10$ per group. ${ }^{*} \mathrm{p}<0.05$ vs. saline by Dunnett's.

Method for Incorporation of ${ }^{32} \mathrm{P}$ or ${ }^{33} \mathrm{P}$ into $\mathrm{ANGIOZYME}{ }^{\mathrm{TM}}$ and Quantitation of Radiolabeled ANIGOZYME ${ }^{\mathrm{TM}}$ in Biological Samples

\section{Internal Radiolabeling}

For internal labeling, ANGIOZYME ${ }^{\mathrm{TM}}$ was synthesized in two halves (5'$\mathrm{g}_{\mathrm{s}} \mathrm{a}_{\mathrm{s}} \mathrm{g}_{\mathrm{s}} \mathrm{u}_{\mathrm{s}} \mathrm{ugcuGAuGaggcc}$ and gaaaggccGaaAgucugB-3'). The $3^{\prime}$ halfribozyme (400 pmol for a $1 \times$ reaction) was 5 ' end-labeled using $2 \mu \mathrm{l}$ of T4 polynucleotide kinase $(30 \mathrm{U} / \mu \mathrm{l}), 1 \mu \mathrm{l}$ of $10 \mathrm{x}$ kinase/ligase buffer $(500 \mathrm{mM}$ HEPES, $30 \mathrm{mM}$ DTT, $50 \mu \mathrm{g} / \mathrm{ml} \mathrm{BSA}, 100 \mathrm{mM} \mathrm{MgCl} 2$ ), $1 \mu$ l of sterile $\mathrm{H}_{2} \mathrm{O}$, and $4 \mu \mathrm{l}\left[\gamma^{32} \mathrm{P}\right]$ or $\left[\gamma^{33} \mathrm{P}\right]$ ATP $(150 \mu \mathrm{Ci} / \mu \mathrm{l})$. The reaction was incubated for 30 $\min$ at $37^{\circ} \mathrm{C}$. The kinase was inactivated by heating at $65^{\circ} \mathrm{C}$ for $5 \mathrm{~min}$.

The two ribozyme halves were then ligated together with the addition of $2 \mu \mathrm{l}$ of T4 RNA ligase $(50 \mathrm{U} / \mu \mathrm{l}), 1 \mu \mathrm{l}$ of kinase/ligase buffer, $1.2 \mu \mathrm{l}$ of 100 $\mu \mathrm{M}$ ATP, and $5.8 \mu \mathrm{l}$ of sterile $\mathrm{H}_{2} \mathrm{O}$. The reaction was incubated for 2 hours at $37^{\circ} \mathrm{C}$. An equal volume of Stop solution (95\% formamide, $20 \mathrm{mM}$ EDTA, $0.05 \%$ bromphenol blue/xylene cyanole $(\mathrm{BB} / \mathrm{XC})$ ) was added and the solution was heated at $95^{\circ} \mathrm{C}$ for 3 min to denature the RNA. The solution was loaded onto a $15 \%$ denaturing PAGE gel and run at $25 \mathrm{~W}$. The gel was exposed for $30 \mathrm{~s}$ on blue film (X-OMATRP XRP-5). The ligated band was cut into small strips and eluted $3 x$ in $600 \mu$ of TE buffer $(10 \mathrm{mM}$ Tris, $1 \mathrm{mM}$ EDTA, $\mathrm{pH}$ 8). The combined supernatants were dried by vacuum centrifugation in a Speed Vac and the pellet resuspended in $100 \mu \mathrm{l}$ of sterile $\mathrm{H}_{2} \mathrm{O}$.

For precipitation, one microliter of glycogen, $8 \mu \mathrm{l}$ of $5 \mathrm{M} \mathrm{NaCl}$, and $700 \mu \mathrm{l}$ of cold $95 \% \mathrm{EtOH}$ were added to the solution and transferred to a $70^{\circ} \mathrm{C}$ freezer for 1 hour. The precipitate was separated by centrifugation at $13,800 \times \mathrm{g}$ for $30 \mathrm{~min}$ at $4^{\circ} \mathrm{C}$. The supernatant was separated by vacuum centrifugation in a Speed Vac and resuspended in $100 \mu$ l of sterile $\mathrm{H}_{2} \mathrm{O}$.

\section{Biological Fluid and Tissue Sample Preparation}

\section{Plasma/Urine}

Radioactivity in $25 \mu$ l thawed plasma or urine was analyzed by scintillation counting, and the remainder reserved for PAGE and phosphorimage analysis. An additional $25 \mu \mathrm{l}$ of thawed plasma or urine was added to an equal volume of Stop buffer and subjected to PAGE and phosphorimage analysis.

\section{Tissue}

Samples were kept on dry ice throughout workup. Weighed tissue samples were pulverized in liquid nitrogen cooled pulverizers. The powdered tissue was added to genomic DNA preparation buffer (1:1 w/v) $\left(43.5 \mathrm{ml} \mathrm{H}_{2} \mathrm{O}, 1 \mathrm{ml}\right.$ $5 \mathrm{M} \mathrm{NaCl}, 0.5 \mathrm{ml} 1 \mathrm{M}$ Tris pH 8.0, $2.5 \mathrm{ml} 0.5 \mathrm{M}$ EDTA, $2.5 \mathrm{ml} \mathrm{10 \%} \mathrm{SDS} \mathrm{and}$ proteinase K (30 units/mg)). Samples were thawed, vortexed, and digested at $50^{\circ} \mathrm{C}$ for $75 \mathrm{~min}$. Digested samples were placed on ice and an equal volume of $2 \mathrm{X}$ Stop buffer was added. The samples were heated at $90^{\circ} \mathrm{C}$ for $5 \mathrm{~min}$, then placed on ice for $5 \mathrm{~min}$. The samples were repeatedly passed through a $20 \mathrm{G}$ needle in order to shear DNA. Samples were heated at $90^{\circ} \mathrm{C}$ for $3 \mathrm{~min}$. The radioactivity in $50 \mu \mathrm{l}$ of the digested tissue was analyzed by scintillation counting, and the remainder reserved for PAGE and phosphorimage analysis.

\section{PAGE and Phosphorimage Analysis}

A $50 \mu \mathrm{l}$ aliquot of the sample was loaded onto a 15\% denaturing PAGE gel ( $15 \%$ acrylamide, $0.5 \%$ SDS in 1 X TBE). After the bromophenol blue tracer reached $2 / 3$ of the gel length, the gel was transferred to a film backing and exposed to a phosphorimaging screen overnight. The percent of full-length ANGIOZYMETM was determined by line quantitation/peak finder analysis (ImageQuaNT, Molecular Dynamics) of each gel lane.

\section{References}

1. Cech, T.R., Zaug, A.J., and Grabowski, P.J. 1981. In vitro splicing of the ribosomal RNA precursor of Tetrahymena: involvement of a guanosine nucleotide in the excision of the intervening sequence. Cell. 27: 487496.

2. Guerrier-Takada, C., Gardiner, K., Marsh, T., Pace, N., and Altman, S. 1983. The RNA moiety of ribonuclease $P$ is the catalytic subunit of the enzyme. Cell. 35: 849-857.

3. Cech, T. R. 1992. Ribozyme engineering. Curr. Opin. Struct. Biol. 2: 605- 609.

4. Beigelman, L., McSwiggen, J.A., Draper, K.G., Gonzalez, C., Jensen, K., Karpeisky, A.M., Modak, A.S., Matulic-Adamic, J., DiRenzo, A.B., Haeberli, P., Sweedler, D., Tracz, D., Grimm, S., Wincott, F.E., Thackray, V.G., and Usman, N. 1995. Chemical modification of hammerhead ribozymes: activity and nuclease resistance. J. Biol. Chem. 270: 2570225708.

5. Agrawal, S., Jiang, Z., Zhao, Q., Shaw, D., Cai, Q., Roskey, A. Channavajjala, L., Saxinger, C., and Zhang, R. 1997. Mixed-backbone oligonucleotides as second generation antisense oligonucleotides: In vitro and in vivo studies. Proc. Natl. Acad. Sci. USA 94: 2620-2625.

6. Bijesterbosch, M.K., Manoharan, M., Rump, E.T., DeVrueh, R L.A., van Veghel, R., Tivel, K.L., Biessen, E.A L., Bennett, C.F., Cook, P.D. and Berkel, T.J.C. 1997. In vivo fate of phosphorothioate antisense oligodeoxynucleotides: predominant uptake by scavenger receptors on endothelial liver cells. Nucl. Acids Res. 25: 3290-3296.

7. Crooke, S.T., Graham, M.J., Zuckerman, J.E., Brooks, D., Conklin, B.S., Cummins, L.L., Grieg, M.J., Guinosso, C.J., Kornbrust, D., Manoharan, M., Sasmor, H.M., Schleich, T., Tivel, K.L. and Griffey, R.H. 1996. Pharmacokinetic properties of several novel oligonucleotide analogs in mice. J. Pharmacol. Exp. Ther. 277: 923-937.

8. DeLong, R.K., Nolting, A., Fisher, M., Chen, Q., Wickstrom, E., Kligshteyn, M., Demirdji, S., Caruthers, M. and Juliano, R. L. 1997. Comparative pharmacokinetics, tissue distribution, and tumor accumulation of phosphorothioate, phosphorodithioate, and methylphosphonate oligonucleotides in nude mice. Antisense Nucleic Acid Drug Dev. 7: 71-77.

9. Fisher, J., Holland, T.K., Pescador, R., Porta, R. and Ferro, L. 1997. Pharmacokinetics, absorption, distribution and disposition of [ $\left.{ }^{125} \mathrm{I}\right]$ oligonucleotide following intravenous or oral administration in the rat. Thrombosis Res. 85: 445-453.

10. Glover, J.M., Leeds, J.M., Mant, T.G.K., Amin, D., Kisner, D.L., Zuckerman, I.E., Geary, R.S., Levin, A.A. and Shanahan, W.R. 1997. Phase I safety and pharmacokinetic profile of an intracellular adhesion molecule-1 antisense oligodeoxynucleotide (ISIS 2302). J. Pharmacol. Exp. Therap. 282: 1173-1180.

11. Lee, W.A., Fishback, J.A., Shaw, J-P., Bock, L.C., Griffin, L.C. and Cundy, K.C. 1995. A novel oligodeoxynucleotide inhibitor of thrombin. II. Pharmacokinetics in the cynomolgus monkey. Pharmaceu. Res. 12: 1943-1947.

12. Cossum, P.A., Sasmor, H., Dellinger, D., Truong, L., Cummins, L., Owens, S. R., Markham, P.M., Shea, P.M. and Crooke, S. 1993. Disposition of the ${ }^{14} \mathrm{C}$-labeled phosphorothioate oligonucleotide ISIS 2105 after intravenous administration to rats. J. Pharmacol. Exp. Ther. 267: 1181-1190.

13. Bayever, E., Iversen, P.L., Bishop, M.R., Sharp, J.G., Tewary, H.K., Arneson, M.A., Pirruccello, S.J., Ruddon, R.W., Kessinger, A., Zon, G. and Armitage, J.0. 1993. Systemic administration of a phosphorothioate oligonucleotide with a sequence complementary to p53 for acute myelogenous leukemia and myelodysplastic syndrome: Initial results of a Phase I trial. Antisense Res. Dev. 3: 383-390.

14. Iversen, P.L., Mata, J., Tracewell, W.G. and Zon, G. 1994. Pharmacokinetics of an antisense phosphorothioate oligodeoxynucleotide against rev from human immunodeficiency virus type 1 in adult male rat following single injections and continuous infusion. Antisense Res. Dev. 4: 43-52.

15. Desjardins, J.P., Sproat, B.S., Beijer, B., Blaschke, M., Dunkel, M., Gerdes, W., Ludwig, J., Reither, V., Rupp, T. and Iversen, P.L. 1996. Pharmacokinetics of a synthetic, chemically modified hammerhead ribozyme against the rat cytochrome P-450 3A2 mRNA after single intravenous injections. J. Pharmacol. Exp. Ther. 278: 1419-1427.

16. Lyngstadaas, S.P., Risnes, S., Sproat, B.S., Thrane, P.S. and Prydz, H.P. 1995. A synthetic, chemically modified ribozyme eliminates amelogenin, the major translation product in developing mouse enamel in vivo. EMBO J. 14: 5224-5229. 
17. Flory, C.M., Pavco, P. A., Jarvis, T.C., Lesch, M.E., Wincott, F.E., Beigelman, L., Hunt, S. W. III, and Schrier, D.J. 1996. Nuclease-resistant ribozymes decrease stromelysin mRNA levels in rabbit synovium following exogenous delivery to the knee joint. Proc. Natl. Acad. Sci. USA. 93: $754-758$.

18. Sioud, M., and Sørensen, D.R. 1998. A nuclease-resistant protein kinase $\mathrm{C} \alpha$ ribozyme blocks glioma cell growth. Nature Biotechnol. 16: 556561.

19. Sioud, M. 1996. Ribozyme modulation of lipopolysaccharide-induced tumor necrosis factor- $\alpha$ production by peritoneal cells in vitro and in vivo. Eur. J. Immunol. 26: 1026-1031.

20. Folkman, J. 1971. Tumor angiogenesis: Therapeutic implications. N. Engl. J. Med. 285: 1182-1186.

21. Thomas, K.A. 1996. Vascular endothelial growth factor, a potent and selective angiogenic agent. J. Biol. Chem. 271: 603-606.

22. Martiny-Baron, G., and Marmé, D. 1995. VEGF-mediated tumour angiogenesis: a new target for cancer therapy. Curr. Opin. Biotechnol. 6: $675-680$.

23. Fong, G.-H., Rossant, J., Gertsenstein, M. and Breitman, M.L. 1995. Role of the Flt-1 receptor tyrosine kinase in regulating the assembly of vascular endothelium. Nature. 376: 66-70.

24. Shibuya, M. 1995. Role of VEGF-FLT receptor system in normal and tumor angiogenesis. Adv. Cancer Res. 67: 281-316.

25. Wincott, F.E., DiRenzo, A., Shaffer, C., Grimm, S., Tracz, D., Workman, C., Sweedler, D., Gonzalez, C., Scaringe, S. and Usman, N. 1995 Synthesis, deprotection, analysis and purification of RNA and ribozymes. Nucl. Acids Res. 23: 2677-2684.

26. National Research Council. 1996. Guide for the Care and Use of Laboratory Animals. National Academy Press, Washington, D.C.

27. Folkman, J. 1995. Angiogenesis in cancer, vascular, and rheumatoid and other disease. Nature Med. 1: 27-31.

28. O'Reilly, M.S., Holmgren, L., Shing, Y., Chen, C., Rosenthal, R.A., Moses, M. Lane, W.S., Cao, Y., Sage, E.H. and Folkman, J. 1994. Angiostatin: a novel angiogenesis inhibitor that mediates the suppression of metastases by a Lewis lung carcinoma. Cell. 79: 315328. 


\section{Further Reading}

Caister Academic Press is a leading academic publisher of advanced texts in microbiology, molecular biology and medical research. Full details of all our publications at caister.com

- MALDI-TOF Mass Spectrometry in Microbiology Edited by: M Kostrzewa, S Schubert (2016) www.caister.com/malditof

- Aspergillus and Penicillium in the Post-genomic Era Edited by: RP Vries, IB Gelber, MR Andersen (2016) www.caister.com/aspergillus2

- The Bacteriocins: Current Knowledge and Future Prospects Edited by: RL Dorit, SM Roy, MA Riley (2016)

www.caister.com/bacteriocins

- Omics in Plant Disease Resistance Edited by: V Bhadauria (2016) www.caister.com/opd

- Acidophiles: Life in Extremely Acidic Environments Edited by: R Quatrini, DB Johnson (2016) www.caister.com/acidophiles

- Climate Change and Microbial Ecology: Current Research and Future Trend

Edited by: J Marxsen (2016)

www.caister.com/climate

- Biofilms in Bioremediation: Current Research and Emerging Technologies

Edited by: G Lear (2016)

www.caister.com/biorem

- Microalgae: Current Research and Applications Edited by: MN Tsaloglou (2016) www.caister.com/microalgae

- Gas Plasma Sterilization in Microbiology: Theory, Applications, Pitfalls and New Perspectives Edited by: H Shintani, A Sakudo (2016) www.caister.com/gasplasma

- Virus Evolution: Current Research and Future Directions Edited by: SC Weaver, M Denison, M Roossinck, et al. (2016) www.caister.com/virusevol

- Arboviruses: Molecular Biology, Evolution and Control Edited by: N Vasilakis, DJ Gubler (2016) www.caister.com/arbo

- Shigella: Molecular and Cellular Biology Edited by: WD Picking, WL Picking (2016) www.caister.com/shigella

-Aquatic Biofilms: Ecology, Water Quality and Wastewater Treatment

Edited by: AM Romaní, H Guasch, MD Balaguer (2016)

www.caister.com/aquaticbiofilms

- Alphaviruses: Current Biology

Edited by: S Mahalingam, L Herrero, B Herring (2016)

www.caister.com/alpha

- Thermophilic Microorganisms

Edited by: F Li (2015)

www.caister.com/thermophile
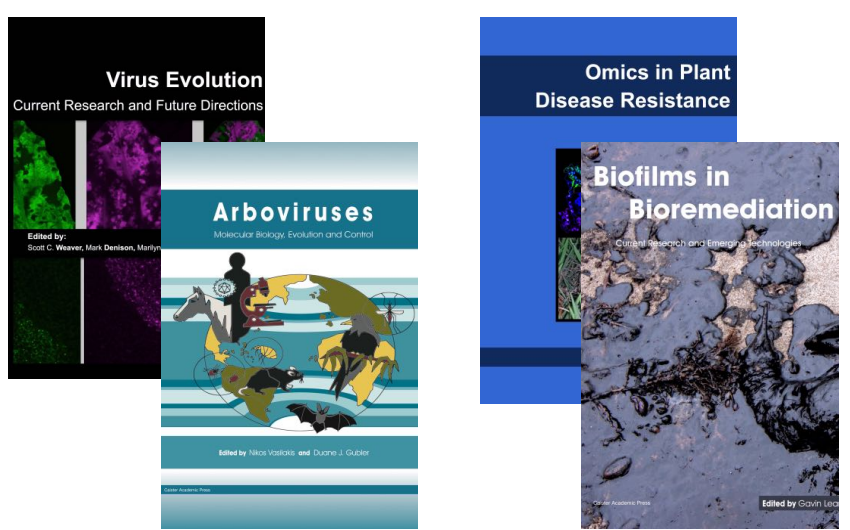
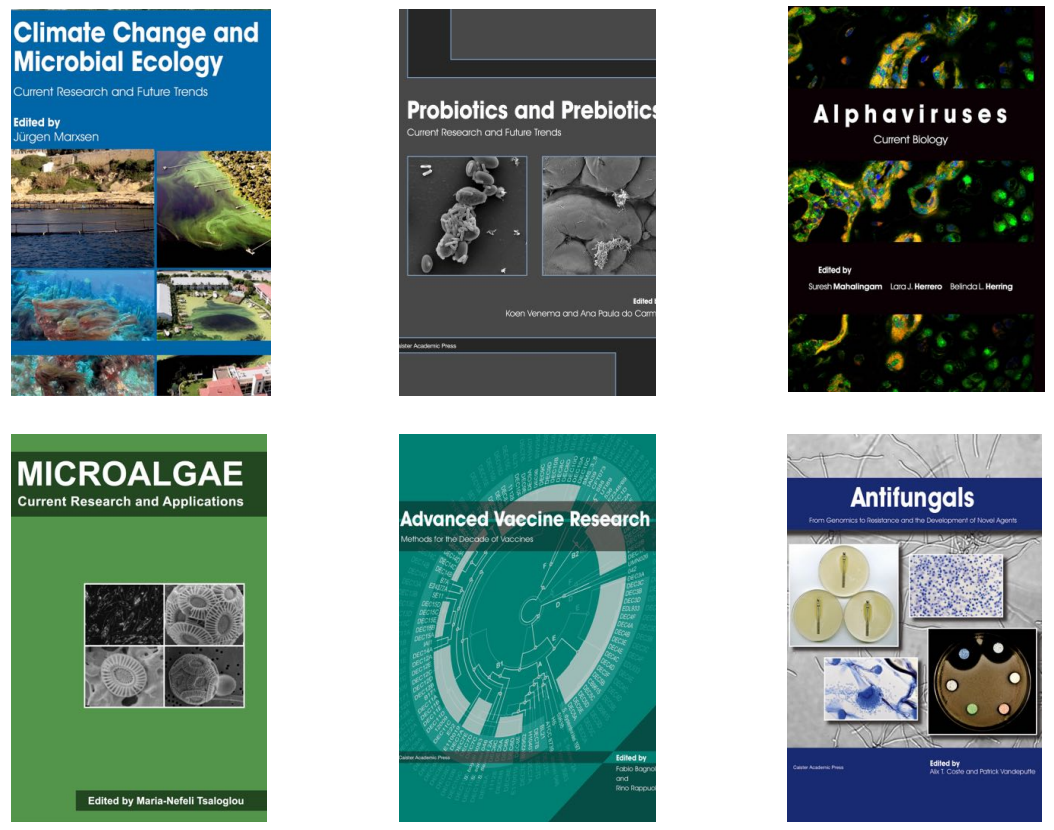

- Flow Cytometry in Microbiology: Technology and Applications Edited by: MG Wilkinson (2015) www.caister.com/flow

- Probiotics and Prebiotics: Current Research and Future Trends Edited by: K Venema, AP Carmo (2015) www.caister.com/probiotics

- Epigenetics: Current Research and Emerging Trends Edited by: BP Chadwick (2015) www.caister.com/epigenetics2015

- Corynebacterium glutamicum: From Systems Biology to Biotechnological Applications

Edited by: A Burkovski (2015)

www.caister.com/cory2

- Advanced Vaccine Research Methods for the Decade of Vaccines

Edited by: F Bagnoli, R Rappuoli (2015)

www.caister.com/vaccines

- Antifungals: From Genomics to Resistance and the Development of Novel Agents

Edited by: AT Coste, P Vandeputte (2015)

www.caister.com/antifungals

- Bacteria-Plant Interactions: Advanced Research and Future Trends Edited by: J Murillo, BA Vinatzer, RW Jackson, et al. (2015) www.caister.com/bacteria-plant

\section{- Aeromonas}

Edited by: J Graf (2015)

www.caister.com/aeromonas

- Antibiotics: Current Innovations and Future Trends

Edited by: S Sánchez, AL Demain (2015)

www.caister.com/antibiotics

- Leishmania: Current Biology and Contro Edited by: S Adak, R Datta (2015) www.caister.com/leish2

- Acanthamoeba: Biology and Pathogenesis (2nd edition) Author: NA Khan (2015)

www.caister.com/acanthamoeba2

- Microarrays: Current Technology, Innovations and Applications Edited by: Z He (2014)

www.caister.com/microarrays2

- Metagenomics of the Microbial Nitrogen Cycle: Theory, Methods and Applications

Edited by: D Marco (2014)

www.caister.com/n2 